\title{
PENGUJIAN KUALITAS MIKROBIOLOGI IKAN EKOR KUNING ASAP DARI PASAR YOUTEFA PAPUA
}

\author{
Kristina Haryati* \\ Jurusan Biologi, Program Studi Biologi, Fakultas MIPA Universitas Cenderawasih Papua \\ Kampus Baru Uncen Waena, Jln. Kampwolker \\ Diterima: 9 September 2020/Disetujui: 10 Desember 2020 \\ ${ }^{\star}$ Korespondensi: kristinaharyati21@gmail.com
}

Cara sitasi: Haryati K. 2020. Kualitas mikrobiologi dan uji biokimia bakteri ikan ekor kuning asap di Pasar Youtefa, Kota Jayapura Papua. Jurnal Pengolahan Hasil Perikanan Indonesia. 23(3): 486-494.

\begin{abstract}
Abstrak
Ikan ekor kuning asap merupakan produk pengolahan tradisional yang dijual di Pasar Youtefa Kota Jayapura. Namun, tingkat kebersihannya mulai dari pascapanen ikan, pengolahan hingga pemasaran belum terjamin. Tujuan dari penelitian tersebut yaitu untuk menentukan mutu mikrobiologis pada ikan ekor kuning asap. Metode penelitian yang dilakukan meliputi uji mikrobiologi, pewarnaan gram bakteri dari isolat terpilih, dan uji biokimia bakteri yang mengacu pada SNI No 01-2332.3:2006 Uji mikrobiologi yang dilakukan yaitu penghitungan total mikroba (TPC) pada ketiga sampel menggunakan metode cawan tuang dengan enam faktor pengenceran. Koloni bakteri yang memiliki morfologi berbeda selanjutnya ditumbuhkan pada media PCA untuk dilakukan pewarnaan gram bakteri dan uji biokimia. Uji biokimia bakteri meliputi uji fermentasi karbohidrat, uji Metil Red-Voges Proskauer (MR-VP), uji sitrat, uji motilitas, uji Triple Sugar Iron Agar (TSIA), uji indol, dan uji katalase. Hasil yang diperoleh yaitu sampel dengan kode A memiliki angka cemaran mikroba yang rendah dibandingkan kode $\mathrm{B}$ dan kode $\mathrm{C}$ pada faktor pengenceran $10^{-6}$. Pewarnaan gram dilakukan untuk isolat terpilih yaitu isolat yang berwarna putih (Isolat A) dengan permukaan rata dan isolat berwarna krem (Isolat B) dengan permukaan agak menonjol. Isolat A bersifat gram positif sedangkan isolat B bersifat gram negatif. Uji biokimia menunjukkan isolat A menghasilkan uji glukosa (+), maltosa (+), MR-VP (+) dan SCA (+) sedangkan untuk isolat B menghasilkan uji glukosa (+), maltosa (+), NA (+) dan SCA (+) sehingga diduga bakteri pada ikan asap yaitu kelompok Staphylococcus dan Salmonella.
\end{abstract}

Kata kunci: ikan asap, pewarnaan gram, total plate count (TPC), uji biokimia bakteri, uji mikrobiologi bakteri.

\section{Microbiological Quality of Smoke Yellow Tail Fish from Youtefa Market Papua}

\begin{abstract}
Smoked yellow tail fish is a traditional processing fish product sold at Youtefa Market in Jayapura City, however, their sanitation status from post-harvest fish, processing to marketing could not be assured. The purpose of this study was to determine the microbiological quality of smoked yellow tail fish. The research included microbiological tests, bacterial gram staining of selected isolates, and bacterial biochemical tests according to Indonesia National Standard. The total microbial count (TPC) was carried out in three samples using the pour plate method with six dilution factors. Bacterial colonies with different morphologies were then inoculated on PCA media for gram staining and biochemical tests. The bacterial biochemical tests included carbohydrate fermentation test, Methyl-red Voges-Proskauer test (MRVP), citrate test, motility test, Triple Sugar Iron Agar (TSIA) test, indole test, and catalase test. The results showed that sample A had lower number of microbial contamination compared to that of sample B and C at a dilution factor of $10^{-6}$. Gram staining was carried out for selected isolates, namely white isolates (isolate A) with a flat surface and cream colored isolates (isolate B) with slightly protruding surfaces. Isolate A was gram positive, while isolate B was gram negative. Biochemical tests showed that isolate A produced glucose (+), maltose (+), MR-VP (+) and SCA (+) tests while isolate B produced glucose $(+)$, maltose $(+)$, NA $(+)$ and SCA tests. $(+)$ so it was suspected that the bacteria in smoked fish were Staphylococcus and Salmonella groups.
\end{abstract}

Keywords: bacterial biochemical test, bacterial microbiological test, gram staining, smoked fish, total plate count(TPC) 


\section{PENDAHULUAN}

Pasar Youtefa merupakan salah satu pasar induk yang terdapat di Kota Jayapura, menyediakan berbagai kebutuhan sandang maupun pangan. Pedagang di Pasar Youtefa terdiri dari pedagang lokal maupun pedagang dan pedagang pendatang. Berdasarkan data, jumlah pedagang yang terdaftar secara resmi oleh pihak pengelola pasar \pm 2.821 pedagang dengan persentase $76 \%$ pedagang pendatang dan $24 \%$ pedagang lokal yang berasal dari berbagai suku (Suhartawan et al. 2017). Pedagang pendatang menjual barang dagangannya pada sebuah toko sedangkan pedagang lokal menjual dagangannya biasanya di daerah terbuka. Dagangan yang dijual oleh pedagang baik pendatang maupun lokal, salah satunya yaitu ikan.

Ikan sebagian besar memiliki kandungan protein yang tinggi, temasuk ikan ekor kuning. Umumnya aasam amino yang terdapat pada ikan yaitu asam amino lisin, metionin, dan triptofan (Onyia et al. 2014). Karena kandungan protein yang tinggi menyebabkan ikan mudah mengalami kerusakan akibat adanya aktivitas mikroba. Faktor yang memengaruhi keberadaan bakteri tersebut terbagi menjadi 2 yaitu faktor internal dan faktor eksternal. Menurut Nurjanah et al. (2011), faktor internal yang mempengaruhi keberadaan bakteri pada ikan yaitu sifat ikan, penggunaan alat tangkap, dan penanganan yang tepat setelah pascapanen. Penanganan ikan setelah pascapanen harus segera dilakukan dengan benar untuk menghindari kerusakan ikan akibat suhu tinggi sebagai akibat aktivitas enzim pada ikan itu sendiri maupun yang berasal dari mikroba (Aberounmand 2010). Penanganan yang benar sebelum pengolahan ikan dilakukan dengan benar, salah satunya yaitu pemberian balok es pada ikan. Setelah itu, maka ikan dapat diolah menjadi berbagai produk, salah satunya yaitu produk ikan asap.

Ikan asap adalah ikan yang dihasilkan melalui teknik pengasapan. Ikan asap yang menjadi target penelitian yaitu ikan ekor kuning asap. Ikan ekor kuning dijadikan ikan asap karena banyaknya masyarakat yang lebih menyukai ikan ekor kuning dibanding ikan cakalang. Pengasapan ikan adalah teknik untuk mengawetkan ikan dengan aroma yang khas (Suroso et al. 2018). Pengasapan yang dilakukan dapat memengaruhi berbagai sifat ikan salah satunya yaitu sifat mikrobiologi ikan. Sifat mikrobiologi berkaitan dengan ada tidaknya cemaran mikroba pada ikan asap sepertikandungan ALT dan bakteri Escherichia coli di bawah nilai maksimum SNI untuk tiap perlakuannya sedangkan kandungan bakteri Salmonella sp. dan Staphylococcus aureus dinyatakan negatif pada seluruh perlakuan (Mardiana et al. 2014); terdeteksinya bakteri Staphylococcus aureus pada ikan layang asap atau pinekuhe (Karimela et al. 2017), tidak ditemukannya bakteri Salmonella pada ikan cakalang asap produksi desa Hative Kota Ambon (Upuolat 2017), ikan tuna sampel B (pasar modern) menunjukkan nilai tertinggi koloni Staphylococcus sp. sedangkan koloni Salmonella sp. menunjukkan hasil negatif pada ketiga sampel (Akerina 2018), E. coli dan Salmonella pada tuna loin asap masih memenuhi SNI (Mailoa et al. 2019).

Keberadaan mikrobajuga tergantung pada sanitasi dan higiene selama proses pengolahan ikan asap hingga proses pemasaran. Proses pengasapan ikan di Indonesia khususnya di Jayapura masih secara tradisional dengan skala rumahan. Oleh karena itu, terkadang sanitasi dan higiene kurang diperhatikan selama proses pengasapan hingga pemasaran. Oleh karena itu tujuan penelitian ini yaitu melakukan isolasi bakteri kontaminan ikan ekor kuning asap dan melakukan uji biokimia bakteri ikan asap tersebut. Hal tersebut merupakan informasi awal dan perlu dilakukan penelitian selanjutnya terhadap kandungan benzopiren pada ikan ekor kuning asap tersebut.

\section{BAHAN DAN METODE}

Bahan utama yang digunakan dalam pengujian mikrobiologi yaitu ikan ekor kuning asap yang diperoleh dari Pasar Youtefa, media nutrient agar (NA) (Merck), $\mathrm{NaCl}$ (Merck). Bahan yang digunakan dalam pewarnaan gram yaitu crystal violet (Merck), lugol (Merck), alkohol 96\%, safranin (Merck), minyak imersi (Merck). Bahan untuk uji biokimia bakteri yaitu media gula (glukosa, laktosa, maltosa, dan sukrosa) (Merck); 
simons citrate agar (Merck), nutrient agar (NA) (Merck), $M R-V P$ broth (Merck). Alat yang digunakan yaitu autoklaf (All American Tipe 75X), timbangan digital (AE ADAM PGW 753), microflow horizontal laminar flow workstation, inkubator (Memmert), stirring hot plate (Favorit), vorteks mixer (model VM-300), colony counter (560 SUNTEX), mikroskop (Olympus CX21) dan alat gelas lainnya (Pyrex).

\section{Metode Penelitian}

Metode penelitian yang dilakukan meliputi uji mikrobiologi, pewarnaan gram bakteri dari isolat terpilih, dan uji biokimia bakteri.

1) Uji mikrobiologi yang dilakukan yaitu penghitungan total mikroba (TPC) pada ikan ekor kuning asap dengan bahan bakar proses pengasapan yang berbeda yaitu kayu (kode sampel A) dan tempurung kelapa (kode sampel B dan C) mengacu pada BSN (2006) SNI 012332.3:2006. Penentuan TPC yang dilakukan menggunakan metode cawan tuang/pour plate yaitu dengan menanamkan contoh ke dalam cawan petri terlebih dahulu kemudian ditambahkan media agar. Pengenceran dilakukan sebanyak 6 faktor pengenceran pada ketiga sampel tersebut. Koloni bakteri yang yang memiliki morfologi berbeda (warna, permukaan dan tepi) selanjutnya ditanamkan pada media PCA untuk dilakukan pewarnaan gram bakteri.

2) Pewarnaan gram yang dilakukan mengacu pada BSN (2011) SNI 2332.9:2011. Pewarnaan gram dilakukan untuk mengetahui koloni bakteri yang diisolasi pada media PCA merupakan kelompok bakteri gram positif atau bakteri gram negatif. Hasil pewarnaan gram yang dilakukan didukung dengan uji biokimia bakteri dari isolat tersebut.
3) Uji biokimia bakteri meliputi uji fermentasi karbohidrat, uji Methil Red-Voges Proskauer (MR-VP), uji sitrat, uji motilitas, uji TSIA, uji indol, dan uji katalase. Uji biokimia mengacu pada BSN (2008) SNI 2897:2008.

\section{Analisis Data}

Data TPC diolah menggunakan Microsoft Office Excel dan dianalisis secara deskriptif dalam bentuk tabel. Data isolasi bakteri dari isolat terpilih termasuk pewarnaan gram dan pengujian biokimia bakteri dianalisis secara deskriptif dan ditampilkan dalam bentuk tabel.

\section{HASIL DAN PEMBAHASAN Uji Mikrobiologi}

Tidak dilakukannya perhitungan karena jumlah mikroba yang dihasilkan terlalu banyak untuk dihitung (TBUD). Tujuan dilakukan pengenceran secara bertingkat yaitu mengurangi jumlah mikroba sehingga dapat dihitung. Jika dilihat jumlah total koloni tiap kode sampel, maka jumlah koloni bakteri yang dihasilkan kode sampel A masih rendah dibanding kode sampel B pada pengenceran $10^{6}$ (Table 1). Namun, jika dibandingkan dengan SNI, maka ketiga kode sampel tersebut memiliki cemaran mikroba yang masih sangat tinggi dan tidak sesuai dengan SNI 2725: 2013 bahwa batas maksimal total bakteri atau TPC adalah 5,0x10 $\mathrm{CFU} / \mathrm{g}$. Keberadaan bakteri dalam suatu produk termasuk produk perikanan merupakan hal penting yang harus diperhatikan oleh produsen.

Faktor yang memengaruhi keberadaan bakteri tersebut terbagi menjadi dua yaitu faktor internal dan faktor eksternal. Menurut Nurjanah et al. (2011), faktor internal yang mempengaruhi keberadaan bakteri pada ikan yaitu sifat ikan, penggunaan alat tangkap, dan

Table 1 TPC Test of Smoked Yellow Tail Fish at Youtefa Market

\begin{tabular}{lrrrrrr}
\hline \multirow{2}{*}{ Sample } & \multicolumn{5}{c}{ TPC of dilution factors (cfu/g) } \\
\cline { 2 - 7 } & $10^{1}$ & $10^{2}$ & \multicolumn{1}{c}{$10^{3}$} & \multicolumn{1}{c}{$10^{4}$} & $10^{5}$ & $10^{6}$ \\
\hline A & $*)$ & $\star$ & $1.19 \times 10^{5}$ & $7.25 \times 10^{5}$ & $5.3 \times 10^{6}$ & $4.45 \times 10^{7}$ \\
B & $*)$ & $\left.{ }^{*}\right)$ & $\left.{ }^{*}\right)$ & $\left.{ }^{*}\right)$ & $1.85 \times 10^{7}$ & $1.15 \times 10^{8}$ \\
C & $*)$ & $*$ & $\left.{ }^{*}\right)$ & $1.78 \times 10^{6}$ & $1.40 \times 10^{7}$ & $1.17 \times 10^{8}$
\end{tabular}

Note: $A=$ smoked fish made with wood chips; $B$ \& $C=$ smoked fish made with coconut shell chips; ${ }^{\star}$ ) showed too numerous to count (TNTC); bacteria was count on $30-300 \mathrm{cfu} / \mathrm{g}$ range. 
penanganan yang tepat setelah pascapanen. Berdasarkan hasil wawancara dengan responden, ikan yang digunakan dalam pengasapan adalah ikan ekor kuning yang segar, dibeli langsung dari nelayan.

Faktor eksternal yang memengaruhi keberadaan bakteri pada ikan asap yaitu sanitasi dan higiene selama pengolahan ikan asap (Palawe et al. 2014; Hadinoto et al. 2016; Amir etal.2018). Berdasarkan hasilwawancara, ikan asap yang dihasilkan masih merupakan industri rumahan dengan memanfaatkan teknologi tradisional yang sederhana dan tidak bisa dijamin tingkat kebersihannya. Dalam proses pengasapan digunakan tatakan pengasapan yang kotor sehingga dapat menyebabkan terkontaminasinya produk yang dihasilkan (Palawe et al. 2014; Mailoa et al. 2019). Tempat penjualan ikan ekor kuning asap memiliki bangunan yang terbuka dan ikan tesebut tidak ditutup sehingga kontaminan dapat berasal dari udara maupun lalat. Tingginya cemaran mikroba juga disebabkan karena masih tingginya kandungan air pada ikan asap (Setiyono \& Sulistyorin 2019). Oleh karena itu, proses pengasapan harus membutuhkan waktu lama untuk menghasilkan ikan asap yang berkualitas. Berdasarkan hasil wawancara, waktu yang dibutuhkan untuk mengasap ikan ekor kuning yaitu 2-3 jam. Hasil wawancara tersebut berbeda dengan hasil penelitian Sakriani (2017) bahwa waktu pengasapan yang baik yaitu 7,5 jam karena dapat menurunkan cemaran mikroba menjadi $1,5 \times 10^{-3} \mathrm{koloni} / \mathrm{gr}$ sedangkan menurut penelitian Darianto et al. (2018) dibutuhkan waktu pengasapan selama 8 jam. Faktor lain penyebab tingginya cemaran mikroba yaitu pencucian ikan menggunakan air laut yang diduga terkontaminasi (Akerina 2018).

\section{Pewarnaan Gram (SNI 2332.9: 2011)}

Pewarnaan gram yang dilakukan yaitu pewarnaan gram dari isolat yang terpilih berdasarkan morfologinya. Isolat terpilih adalah isolat yang memiliki morfologi khususnya warna yang berbeda saat pengamatan jumlah koloni. Isolat terpilih ada dua yaitu isolat yang berwarna putih (isolat A) dengan permukaan rata dan isolat berwarna krem (isolat B) dengan permukaan agak menonjol. Faktor yang memengaruhi variasi bakteri yaitu umur dan syarat pertumbuhan (Hidayat et al. 2006), dan warna koloni. Isolat terpilih tersebut ditumbuhkan kembali pada media NA untuk dilakukan pewarnaan gram dan uji biokimia.

Tujuan dilakukan pewarnaan gram yaitu membedakan bakteri ke dalam dua kelompok yaitu bakteri gram positif dan bakteri gram negatif. Hasil pengamatan pewarnaan gram menunjukkan bahwa isolat A bersifat gram postif dan gram negatif sedangkan isolat B bersifat gram negatif (Table 2). Pada saat dilakukan pewarnaan gram, bakteri gram positif akan mempertahankan warna ungu dari kristal violet sedangkan bakteri gram negatif akan mempertahankan warna merah dari safranin (Anuar et al. 2014). Perbedaan warna yang dipertahankan menunjukkan perbedaan struktur dinding sel yaitu dinding sel bakteri gram positif mengandung peptodoglikan yang tebal dan membran dalam sehingga dapat mengikat warna kristal violet sedangkan dinding sel bakteri gram negatif mengandung banyak lipid sehingga mengikat warna dari safranin (Hamidah et al. 2019; Fitri \& Yasmin 2011; Anuar et al. 2014). Bentuk koloni bakteri pewarnaan gram yaitu berbentuk basil atau batang, dan berbentuk kokus atau bulat. Kelompok bakteri kokus ada yang bergerombol membentuk koloni dan ada

Table 2 Morphology and Gram Staining of Isolates

\begin{tabular}{lll}
\hline Characteristics & \multicolumn{1}{c}{ Isolate A } & \multicolumn{1}{c}{ Isolate B } \\
\hline Colour & White & Cream \\
Surface & Flat & Stand out \\
Gram & Positive and Negative & Negative \\
Gram staining & Pink and violet & Pink \\
Colony form & Rod shape, round shape & Rod shape, round shape \\
\hline
\end{tabular}


yang terpisah sedangkan kelompok bakteri yang berbentuk batang dapat membentuk rantai pendek. Bentuk-bentuk sel bakteri yang diamati dalam pewarnaan gram adalah cara mengetahui karakteristik suatu bakteri (Safrida et al. 2012).

\section{Uji Biokimia Bakteri}

Uji Biokimia dilakukan untuk mengetahui reaksi yang dihasilkan oleh bakteri pada media yang digunakan (Harti 2015). Uji biokimia yang dilakukan sangat penting untuk mengidentifikasi mikroorganisme.

Uji gula yang dilakukan bertujuan mengetahui kemampuan bakteri dalam menfermentasi karbohidrat, yang ditandai dengan terjadinya perubahan warna menjadi kuning, serta dihasilkannya gas. Berdasarkan data, uji gula dinyatakan positif untuk isolat $A$ dan isolat B yaitu pada glukosa dan manitol. Hasil tersebut mengindikasikan bahwa bakteri memanfaatkan glukosa dan manitol untuk keberlangsungan fermentasi karbohidrat dan terbentuk gas. Perubahan media menjadi warna kuning disebabkan karena indikator fenol merah. Bakteri dikatakan dapat memfermentasi semua kabohidrat jika dalam prosesnya terjadi pengonversian piruvat menjadi asam, yang selanjutnya diubah menjadi gas $\mathrm{H}_{2}$ dan $\mathrm{CO}_{2}$ yang terperangkap dalam tabung durham (Mahon et al. 2014).

Uji simmone citrate agar (SCA) adalah komponen penting dalam siklus Krebs sebagai hasil reaksi Koenzim A dan asam Oksaloasetat dengan bantuan enzim sitrase. Dalam reaksi tersebut, terjadi ikatan $\mathrm{CO}_{2}$ dengan $\mathrm{Na}$ dan $\mathrm{H}_{2} \mathrm{O}$ membentuk $\mathrm{Na}_{2} \mathrm{CO}_{3}$ sehingga medium bersifat basa. Sifat basa pada medium inilah yang akan menyebabkan terjadi perubahan warna dari hijau menjadi biru jika bereaksi dengan indikator bromthymol blue (Cappuccino \& Sherman 2005 dalam Fallo \& Sine 2016). Berdasarkan data hasil uji MR dinyatakan positif untuk isolat $\mathrm{A}$ dan isolat B sedangkan uji VP dinyatakan positif hanya untuk isolat A (Table 3). Isolat A dinyatakan positif karena terjadi perubahan warna dan agak keruh. Hasil tersebut menunjukkan bahwa isolat A mampu menghasilkan asam. Menurut Rahayu \& Gumilar (2017), uji MRVP dilakukan dengan tujuan menfermentasi karbohidrat menjadi produk akhir asam yang stabil dan untuk mendeteksi asetonin (Rahayu \& Gumilar 2017; Sunatmo 2007 dalam Fallo \& Sine 2016; Ulfa et al. 2016).

Motilitas atau pergerakan bakteri dipengaruhi oleh gerakan aktif maupun gerakan pasif. Gerakan aktif bakteri terjadi karena adanya flagela sedangkan gerakan pasif bakteri terjadi karena adanya gerak Brown. Faktor yang mempengaruhi pengamatan motilitas bakteri yaitu media biakan yang baru, produksi asam dan produk racun (Pattuju et al. 2014). Berdasarkan data, terjadi pergerakan isolat bakteri yang diinokulasi pada media tegak NA untuk isolat B sedangkan untuk isolat $A$ tidak terjadi pergerakan. Isolat $A$ dan isolat $\mathrm{B}$ merupakan kelompok bakteri gram negatif yang berbentuk basil atau batang. Hasil tersebut sesuai dengan pernyataan Pattuju et al. (2014) bahwa sebagian besar bakteri bentuk spiral dan bakteri berbentuk basil bersifat motil, sedangkan bakteri berbentuk bulat atau kokus bersifat immotil.

Berdasarkan data, isolat yang menunjukkan reaksi positif terhadap uji TSIA yaitu isolat B (Table 3). Hasil tersebut menunjukkan bahwa bakteri pada isolat tersebut dapat memfermentasi glukosa dan menghasilkan asam. Hasil tersebut juga didukung oleh pernyataan Antriana (2014) dan Anggraini et al. (2016). Menurut Rahayu dan Gumilar (2017), uji indol dilakukan dengan tujuan untuk mengidentifikasi bakteri yang dapat menghasilkan indol dengan menggunakan enzim triptofanase. Hal tersebut menunjubakteri tersebut mengandung enzim triptophanase (Ulfa et al. 2016). Berdasarkan hasil, isolat yang mengandung enzim triptophanse yaitu isolat $B$ karena ditandai dengan terbentuknya cincin berwarna merah atau dengan artian isolat B merupakan kelompok yang menghasilkan ensim triptophanase (Table 3). Uji katalase dilakukan dengan tujuan mengetahui bakteri yang memiliki kemampuan untuk menghasilkan enzim katalase yang ditandai dengan pemecahan $\mathrm{H}_{2} \mathrm{O}_{2}$ menjadi $\mathrm{H}_{2} \mathrm{O}$ dan $\mathrm{O}_{2}$ dalam bentuk gelembung gas (Hayati et al. 2019).

Penelitian yang dilakukan oleh Susanti et al. (2016), diperoleh hasil TSIA 
lereng merah alkali, dasar kuning acid, gas (-), $\mathrm{H}_{2} \mathrm{~S}(+)$; uji SIM positif; uji indol negatif; motility positif; SCA diperoleh hasil (-); uji MR (+) positif warna merah dan VP (-). Penelitian yang dilakukan oleh Karimela et al. (2013) terhadap 66 galur uji bakteri Staphylococcus sp. dari ikan layang asap, diperoleh hanya 53 galur yang memberikan reaksi positif terhadap uji katalase; sebagian besar isolat memberikan reaksi positif terhadap fermentasi karbohidrat dan MR; sebagian besar isolat memberikan reaksi negatif terhadap uji indol, VP, dan SCA.

Berdasarkan hasil uji biokimia bakteri yang dilakukan, dapat diidentifikasi bakteri isolat A diduga merupakan kelompok bakteri Staphylococcus. Hasil uji biokimia yang diperoleh didukung oleh hasil penelitian yang dilakukan oleh Karimela et al. (2017). Kelompok Staphylococcus merupakan kelompok bakteri yang berbentuk bulat atau kokus dengan diameter $0,5-1,0 \mathrm{~mm}$, berkelompok, termasuk bakteri gram positif yang berwarna ungu (Foster 2008). Pernyataan tersebut juga didukung oleh dilakukannya pewarnaan gram bakteri sehingga untuk isolat A yang diduga merupakan kelompok bakteri Staphylococcus adalah bakteri gram positif. Untuk membedakan bakteri Staphylococcus dan Streptococcus, maka dilakukan uji katalase, dimana bakteri Streptococcus memberikan hasil negetif sedangkan Staphylococcus memberi hasil positif.

Bakteri Staphylococcus merupakan parasit bagi manusia maupun hewan karena menghasilkan endotoksin (Ijong 2015). Faktor yang menyebabkan ikan asap terkontaminasi bakteri Staphylococcus yaitu interaksi antara produsen dan konsumen dengan ikan asap yang dijual, produsen tidak memperhatikan sanitasi dan higiene mulai dari pascapanen ikan, proses pengolahan menjadi ikan asap hingga proses pemasaran (Ekawati et al. 2005). Berdasarkan hasil survei lapangan, para pedagang menjual ikan asap secara terbuka sehingga menyebabkan terjadinya kontaminasi.

Jika dilihat berdasarkan hasil uji biokimia bakteri, maka isolat B diduga merupakan kelompok Salmonella. Pertumbuhan Salmonella sangat cepat jika suhu lingkungan tinggi. Kelompok Salmonella merupakan baktri gram negatif yang berwarna merah muda. Hasil pewarnaan gram yang dilakukan menunjukkan bahwa Salmonella merupakan kelompok bakteri gram negatif. Menurut Akerina (2018), bakteri Salmonella dapat hidup pada suhu $5-47^{\circ} \mathrm{C}$ sehingga bakteri tersebut tidak akan hidup pada suhu pengasapan. Namun, produk ikan asap kemungkinan dapat terkontaminasi karena faktor membiarkan makanan (ikan asap) dalam kondisi terbuka merupakan sarana penyebaran bakteri serta kondisi lingkungan yang kotor memungkinkan penyebaran mikroba dan partikel-partikel kuman terbawa masuk ke ikan asap (Susanti et al. 2016).

Table 3 Results of the bacterial biochemical test of selected isolates

\begin{tabular}{lll}
\hline \multicolumn{1}{c}{ Test } & Isolate A & Isolate B \\
\hline Glucose & Positive & Positive \\
Lactose & Negative & Negative \\
Sucrose & Negative & Negative \\
Maltose & Negative & Positive \\
Mannitol & Positive & Positive \\
VP & Positive & Negative \\
MR & Positive & Positive \\
SCA & Negative & Positive \\
Motility & Negative & Positive \\
TSIA & Negative & Positive
\end{tabular}




\section{KESIMPULAN}

Uji mikrobiologis menunjukkan bahwa cemaran mikroba pada ikan ekor kuning asap masih tergolong tinggi. Bakteri yang terdapat pada ikan ekor kuning asap adalah kelompok bakteri gram positif dan bakteri gram negatif dengan bentuk batang dan bulat. Uji biokimia bakteri menunjukkan bahwa bakteri yang terdapat pada ikan ekor kuning asap diduga merupakan kelompok Staphylococcus dan Salmonella.

\section{UCAPAN TERIMA KASIH}

Ucapan terima kasih penulis sampaikan kepada FMIPA yang telah mendanai penelitian ini dalam bentuk dana PNBP. Penulis juga mengucapkan terima kasih berbagai pihak yang telah membantu penulis dalam menganalisis sampel pada Laboratorium Mikrobiologi FMIPA Uncen.

\section{DAFTAR PUSTAKA}

Aberoumand A. 2010. Edible gelatin from some fishes skins as affected by chemical tratments. World Journal of Fish and Marine Sciences. 2(1): 59-61.

Akerina FO. 2018. Cemaran mikroba pada ikan tuna asap di beberapa pasar tradisional Tobelo, Halmahera Utara, Indonesia. Jurnal Akuakultur, Pesisir dan Pulau-Pulau Kecil. 2(1): 17-21.

Amir N, Metusalach, Fahrul. 2018. Mutu dan keamanan pangan produk ikan asap di Kabupaten Bulukumba Provinsi Sulawesi Selatan. Jurnal Agribisnis Perikanan. 11(2):15-21.

Anggraini R, Aliza D, Mellisa S. 2016. Identifikasi bakteri Aeromonas hydrophila dengan uji mikrobiologi pada ikan lele dumbo (Clarias gariepinus) yang dibudidayakan di Kecamatan Baitussalam Kabupaten Aceh Besar. Jurnal Ilmiah Mahasiswa Kelautan dan Perikanan Unsyiah. 1(2): 270-286.

Antriana N. 2014. Isolasi bakteri asal saluran pencernaan rayap pekerja (Macrotermes spp.). Saintifika. 16(1): 18 - 28.

Anuar W, Dahliaty A, Jose C. 2014. Isolasi bakteri selulolitik dari perairan Dumai. JOM FMIPA. 1(2): 149-159.
[BSN] Badan Standardisasi Nasional. 2006. Cara uji mikrobiologi-bagian 3: penentuan angka lempeng total (ALT) pada produk perikanan. SNI 2332.3:2006. Jakarta (ID): Badan Standardisasi Nasional.

[BSN] Badan Standardisasi Nasional. 2008. Metode pengujian cemaran mikroba dalam daging, telur, susu, serta hasil olahannya. SNI 2897:2008. Jakarta (ID): Badan Standardisasi Nasional.

[BSN] Badan Standardisasi Nasional. 2011. Cara uji mikrobiologi-bagian 9: penentuan Staphylococcus aureus pada produk perikanan. SNI 2332.9:2011. Jakarta (ID): Badan Standardisasi Nasional.

Darianto, Sitohang HTS, Amrinsyah. 2018. analisa faktor-faktor yang mempengaruhi proses pengasapan pada mesin pengasapan ikan lele. Journal of Mechanical Engineering Manufactures Materials and Eenergy. 2(2): 56-66.

Ekawati P, Martini, Yuliawati. 2005. Kontaminasi Staphylococcus aureus pada Ikan Asap di Tingkat Produsen dan Penjual di Semarang. Jurnal Kesehatan Masyarakat Indonesia. 2(2):70-76.

Fallo G, Sine Y. 2016. Isolasi dan uji biokimia bakteri selulolitik asal saluran pencernaan rayap pekerja (Macrotermes spp.). Bio Edu : Jurnal Pendidikan Biologi. 1(2): 2729.

Fitri L, Yasmin Y. 2011. Isolasi dan pengamatan morfologi koloni bakteri kitinolitik. Jurnal Ilmiah Pendidikan Biologi, Biologi Edukasi. 3(2): 20-25.

Foster T. 2008. Staphylococcus. Diakses melalui http://gsbs.utmb.edu/microbook/ ch012.htm Medmicro Chapter 12. [19/10/2020].

Hadinoto S, Kolanus JPM, Manduapessy KRW. 2016. Karakteristik mutu ikan cakalang (Katsuwonus pelamis) asap menggunakan asap cair dari tempurung kelapa. Majalah BIAM. 12(1): 20-26.

Hamidah MN, Rianingsih L, Romadhon. 2019. Aktivitas antibakteri isolat bakteri asam laktat dari peda dengan jenis ikan berbeda terhadap E. coli dan S. aureus. Jurnal Ilmu dan Teknologi Perikanan. 1(2): 11-21. 
Harti A S. 2015. Mikrobiologi Kesehatan. Yogyakarta: ANDI

Hayati LN, Tyasningsih W, Praja RN, Chusniati S, Yunita MN, Wibawati PA. 2019. Isolasi dan identifikasi Staphylococcus aureus pada susu kambing peranakan etawah penderita mastitis subklinis di Kelurahan Kalipuro, Banyuwangi. Jurnal Medik Veteriner. 2(2): 76-82.

Hidayat N, Padaga MC, Suhartini S. 2006. Mikrobiologi Industri. Yogyakarta: ANDI

Ijong FG. 2015. Mikrobiologi Perikanan dan Kelautan. Jakarta (ID): Rineka Cipta

Karimela EJ, Ijong FG, Agustin AT. 2013. Staphylococcus sp. pada ikan layang (Decapterus russelii) asap pinekuhe produk khas Sangihe. Jurnal Media Teknologi Hasil Perikanan. 1(2): 59-63.

Karimela EJ, Ijong FG, Dien HA. 2017. Karakteristik Staphylococcus aureus yang di isolasi dari ikan asap pinekuhe hasil olahan tradisional Kabupaten Sangihe. Jurnal Pengolahan Hasil Perikanan Indonesia. 20(1): 188-198.

Kartikasari AM, Hamid IS, Purnama MTE, Damayanti R, Fikri F, Praja RN. 2019. Isolasi dan identifikasi bakteri Escherichia coli kontaminan pada daging ayam broiler di rumah potong ayam Kabupaten Lamongan. Jurnal Medik Veteriner. 2(1): 66-71.

Mahon C, Lehman D, Manuselis G. 2014. Textbook of Diagnostic Microbiology. 5th Edition. Philadelphia: Elsevier.

Mailoa MN, Lokollo E, Nendissa DM, Harsono PI. 2019. Karakteristik mikrobiologi dan kimiawi ikan tuna asap. Jurnal Pengolahan Hasil Perikanan Indonesia. 22(1): 89-99.

Mardiana N, Waluyo S, Ali M. 2014. Analisis kualitas ikan sembilang (Paraplotosus albilabris) asap di kelompok pengolahan ikan "mina mulya" Kecamatan Pasir Sakti Lampung Timur. Jurnal Teknik Pertanian Lampung. 3(3): 283-290.

Nurjanah, Nurhayati T, Zakaria R. 2011. Kemunduran mutu ikan gurami (Osphronemus gouramy) pasca kematian pada penyimpanan suhu chilling. AKUATIK-Jurnal Sumberdaya Perairan. 5(2): 11-18
Palawe JFP, Sewetja IK, Mandey LC. 2014. Karakteristik mutu mikrobiologis ikan pinekuhe Kabupaten Kepulauan Sangihe. Jurnal Ilmu dan Teknologi Pangan. 2(2): 38-47

Pattuju SM, Fatimawali, Manampiring A. 2014. Identifikasi bakteri resisten merkuri pada urine, feses dan kalkulus gigi pada individu di Kecamatan Malalayang, Manado, Sulawesi Utara. Jurnal e-Biomedik. 2(2): 532-540.

Rahayu SA, Gumilar MH. 2017. UJI cemaran air minum masyarakat sekitar margahayu raya bandung dengan identifikasi bakteri Escherichia coli. Indonesian Journal of Pharmaceutical Science and Technology. 4(2): 50-56.

Safrida YD, Yulvizar C, Devira CN. 2012. Isolasi dan karakterisasi bakteri berpotensi probiotik pada ikan kembung (Rastrelliger sp.). Depik. 1(3): 200-203.

Sakriani. 2017. Praktik higiene dan sanitasi terhadap kualitas ikan asap di tempat pengasapan ikan di kota ternate. PROMOTIF: Jurnal Kesehatan Masyarakat.7(2): 167-174.

Setiyono RFRS, Sulistyorin L. 2019. Korelasi kualitas fisik ikan asap dan fasilitas kegiatan higiene dan sanitasi dengan keberadaan bakteri Escherichia coli pada ikan asap. Jurnal Kesehatan Lingkungan. 11(4): 276-285.

Suhartawan V, Ridjal AM, Mariningrum I. 2017. Toleransi pedagang lokal dalam aktivitas perdagangan di Pasar Tradisional Youtefa, Abepura. Jurnal Mahasiswa Jurusan Arsitektur Universitas Brawijaya.

Suroso E, Utomo TP, Hidayati S, Nuraini A. 2018. Pengasapan ikan kembung menggunakan asap cair dari kayu karet hasil redestilasi. Jurnal Pengolahan Hasil Perikanan Indonesia. 21(1): 42-53.

Susanti, Fusvita A, Janhar IA. 2016. Identifikasi Salmonella sp. pada ikan asap di pasar tradisional Kota Kendari. Biowallacea. 3(2): 467-47.

Ulfa A, Suarsini E, Al Muhdhar MHI. 2016. Isolasi dan uji sensitivitas merkuri pada bakteri dari limbah penambangan emas 
di Sekotong Barat Kabupaten Lombok Barat: Penelitian Pendahuluan. Proceeding Biology Education Conference. 13(1): 793799.

Upuolat U. 2017. Analisis keberadaan bakteri Escherichia coli dan Salmonella pada proses pengolahan di tempat produksi ikan cakalang (Katsuwonus pelamis) asap di desa Hative Kecil. [Skripsi]. Ambon: Teknologi Hasil Perikanan. Universitas Pattimura. 